\title{
KSIAŻKA LITERACKA W POLSCE W LATACH 1990-2010 W ŚWIETLE STATYSTYKI
}

\author{
Jadwiga Sadowska \\ Zakład Informacji Naukowej \\ i Bibliotekoznawstwa \\ Uniwersytet w Białymstoku
}

Statystyka wydawnicza, literatura piękna polska i obca, przekłady literatury pięknej, książka literacka w Polsce

Rok 1990, uznawany za poczatek wolnego rynku książi w Polsce, oznaczał równocześnie koniec monopolu państwa w działalności wydawniczej, koniec planowanej i kontrolowanej przez państwo produkcji wydawniczej, ale też jednocześnie koniec mecenatu państwa wobec znacznej części środowiska pisarskiego i wydawniczego ${ }^{1}$. Rok ten stanowił poczatek istotnych zmian w finansowaniu i organizacji oficyn wydawniczych. Pojawili się nowi prywatni wydawcy, przy czym dla wielu z nich działalność wydawnicza była działalnościa uboczną, czasem kończąca się na wydaniu kilku książek. Książki, czasopisma i inne typy publikacji stały się towarem, a działalność wydawnicza rodzajem usług opartych na zasadach gospodarki rynkowej. Od tego momentu praktycznie nie istniały żadne przeszkody w zarejestrowaniu firmy wydawniczej czy poligraficznej, a także w zakupie praw autorskich oraz wydawaniu dzieł polskich lub zagranicznych, książek czy czasopism. Przypomnijmy też, że w maju 1990 r. zlikwidowano Główny Urząd Kontroli Prasy, Publikacji i Widowisk, czyli urzędową cenzurę, co umożliwiło prowadzenie swobodnej działalności wydawniczej².

Od roku 1990 na rynku wydawniczym zaczęły zachodzić zmiany nie tylko jakościowe, ale przede wszystkim ilościowe - zwiększyła się istotnie liczba wydawców oraz wydawanych książek i czasopism, zmniejszały się natomiast nakłady, zmieniała się dynamika produkcji książek i czasopism, zmieniały się też proporcje udziału piśmiennictwa polskiego i przekładów. Tendencje rozwojowe rynku czasopism i książek naukowych po 1990 r. w aspekcie statystycznym

${ }^{1}$ O sytuacji pisarzy w PRL zob. np.: T. Mielczarek: Pisarze w PRL: „pieszczochy władzy" czy ofiary systemu? W: Niewygodne dla władzy: ograniczanie wolności słowa na ziemiach polskich w XIX i XX w. Zbiór studiów pod red. Doroty Degen i Jacka Gzelli. Toruń 2010, s. 213-231.

${ }^{2}$ O początkowym okresie zmian na rynku wydawców zob. m.in. M. Tobera: Rynek książki w Polsce (1989-2000). „Przeglad Biblioteczny” 2001, z. 3, s. 237-241 oraz J. Sadowska: Wybrane aspekty polskiego rynku wydawniczego po 1989 r. w świetle statystyki. „Zagadnienia Informacji Naukowej" 2004, nr 2, s. 30-40. 
opisała Małgorzata Korczyńska-Derkacz ${ }^{3}$. Statystyczny obraz przekładów ksiażek obcych na język polski był tematem artykułu Anny Musioł . Przedmiotem przedstawionego tekstu jest książka literacka rozpatrywana z podobnego punktu widzenia, tj. ukazania tendencji rozwojowych na podstawie danych liczbowych. Źródłem analizy są dane zawarte w roczniku statystycznym „Ruch Wydawniczy w Liczbach" z lat 1990-2010, opracowywanym w Bibliotece Narodowej na podstawie bieżącej bibliografii narodowej i egzemplarza obowiązkowego dokumentów dostarczanych przez wydawców. Za punkt odniesienia przyjęto rok 1990, choć czasami porównawczo przytaczane są dane z całego okresu powojennego (1944-2010)5.

Dane liczbowe potwierdzaja stały wzrost ogólnej liczby ksiażek, jak również książek z literatury pięknej. Porównując wysokość produkcji wydawniczej z pierwszego roku po transformacji społeczno-ustrojowej i 2010 r. można stwierdzić, że w okresie 20 lat od wprowadzenia wolnego rynku liczba wydawanych książek prawie potroiła się, natomiast liczba książek literackich wzrosła prawie czterokrotnie. Średnio książki literackie stanowia jedną piątą wszystkich wydawanych w tym czasie książek, choć w poszczególnych latach występowały wahania dochodzące prawie do 6 punktów (najniższy wskaźnik w 2000 r., niskie w 1996 i 2002, najwyższy w 1993 i 1998). Szczegóły ilustruje tabela 1 i wykres 1.

Tabela 1

Liczba książek ogółem oraz literatury pięknej w latach 1990-2010

\begin{tabular}{|c|c|c|c|}
\hline Rok & $\begin{array}{c}\text { Liczba książek } \\
\text { ogółem }\end{array}$ & $\begin{array}{c}\text { Liczba książek } \\
\text { literatury pięknej }\end{array}$ & $\begin{array}{c}\text { Wskaźnik } \\
\text { \% literatury pięknej } \\
\text { do książek ogółem }\end{array}$ \\
\hline 1990 & 10242 & 1573 & 15,3 \\
\hline 1991 & 10688 & 1996 & 18,7 \\
\hline $1992^{*}$ & 10915 & 2430 & 22,3 \\
\hline $1993^{*}$ & 10657 & 2484 & 23,3 \\
\hline $1994^{*}$ & 13442 & 3001 & 22,3 \\
\hline 1995 & 11925 & 2556 & 17,0 \\
\hline 1996 & 14104 & 2397 & 21,0 \\
\hline 1997 & 15996 & 3365 & 23,3 \\
\hline 1998 & 16462 & 3839 & 18,5 \\
\hline 1999 & 19192 & 3560 & 18,6 \\
\hline 2000 & 21647 & 4018 & \\
\hline
\end{tabular}

${ }^{3}$ M. Korczyńska-Derkacz: Książka naukowa w Polsce w latach 1991-2005 - tendencje rozwojowe. „Zagadnienia Informacji Naukowej” 2006, nr 2, s. 91-108; Także: Tendencje rozwojowe polskiego czasopiśmiennictwa naukowego w latach 1991-2005. „Zagadnienia Informacji Naukowej" 2006, nr 1, s. 75-92.

${ }^{4}$ A. Musioł: Książka zagraniczna w Polsce w latach 1991-2010 w świetle statystyki. „Zagadnienia Informacji Naukowej” 2011, nr 2, s. 89-101.

${ }^{5}$ W odniesieniu do lat 1992-1994 niektóre dane szczegółowe zawarte w rocznikach 1992, 1993, 1994 „Ruchu Wydawniczego w Liczbach” obarczone są kilkuprocentowym błędem. Zostały one skorygowane w zestawieniach retrospektywnych oraz w tablicach zawartych w uwagach wstępnych do „Ruchu Wydawniczego w Liczbach” 2004, R. 50, s. 5-12, nie zostały jednak skorygowane w odniesieniu do przekładów. 


\begin{tabular}{|c|c|c|c|}
\hline 2001 & 19189 & 3523 & 18,3 \\
\hline 2002 & 19246 & 3303 & 17,2 \\
\hline 2003 & 20681 & 4429 & 21,4 \\
\hline 2004 & 22475 & 4973 & 22,1 \\
\hline 2005 & 19999 & 4308 & 21,5 \\
\hline 2006 & 24640 & 4782 & 19,4 \\
\hline 2007 & 25226 & 5334 & 21,1 \\
\hline 2008 & 28248 & 5935 & 21,0 \\
\hline 2009 & 28128 & 5884 & 20,9 \\
\hline 2010 & 29539 & 6190 & 20,9 \\
\hline
\end{tabular}

Źródło: Opracowanie własne na podstawie „Ruchu Wydawniczego w Liczbach”.

* Uwzględniono skorygowaną liczbę książek w latach 1992-19946.

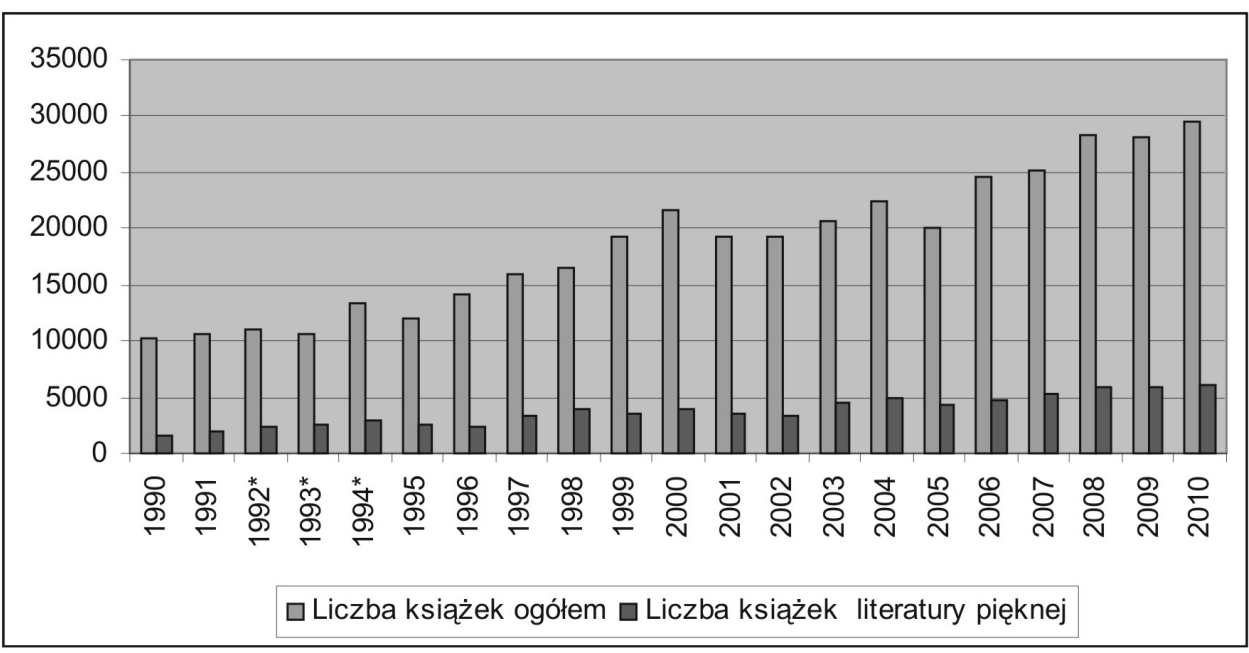

Wykres 1. Książki literackie na tle książek ogółem

Warto też spojrzeć na rozkład liczbowy książek w podziale na trzy podstawowe typy: książki naukowe, popularne i literaturę piękną. Ilustruje to tabela 2 i wykres 2.

Tabela 2

Liczba książek według typów

\begin{tabular}{|c|c|c|c|}
\hline Rok & $\begin{array}{c}\text { Liczba książek } \\
\text { naukowych }\end{array}$ & $\begin{array}{c}\text { Liczba książek } \\
\text { popularnych }\end{array}$ & $\begin{array}{c}\text { Liczba książek } \\
\text { literatury pięknej }\end{array}$ \\
\hline 1990 & 4801 & 2444 & 1573 \\
\hline 1991 & 4965 & 2447 & 1996 \\
\hline $1992^{*}$ & 4518 & 2694 & 2430 \\
\hline $1993^{*}$ & 3569 & 3037 & 2484 \\
\hline $1994^{*}$ & 5341 & 3500 & 3001 \\
\hline 1995 & 4270 & 3227 & 2556 \\
\hline
\end{tabular}

${ }^{6}$ Zob. Uwagi wstępne, „Ruch Wydawniczy w Liczbach” 2004, R. 50, s. 5-12 oraz tablica 40. 


\begin{tabular}{|l|l|l|l|}
\hline 1996 & 5671 & 3885 & 2397 \\
\hline 1997 & 6039 & 4135 & 3365 \\
\hline 1998 & 6089 & 4089 & 3839 \\
\hline 1999 & 8289 & 4757 & 3560 \\
\hline 2000 & 8625 & 5890 & 4018 \\
\hline 2001 & 7867 & 5120 & 3523 \\
\hline 2002 & 8850 & 4530 & 3303 \\
\hline 2003 & 8257 & 5159 & 4429 \\
\hline 2004 & 9329 & 5654 & 4973 \\
\hline 2005 & 8366 & 4999 & 4308 \\
\hline 2006 & 11126 & 6198 & 4782 \\
\hline 2007 & 10662 & 6927 & 5334 \\
\hline 2008 & 12158 & 7827 & 5935 \\
\hline 2009 & 12140 & 7588 & 5884 \\
\hline 2010 & 13015 & 7493 & 6190 \\
\hline
\end{tabular}

Źródło: Opracowanie własne na podstawie „Ruchu Wydawniczego w Liczbach”.

* Zob. uwagi do tabeli 1.

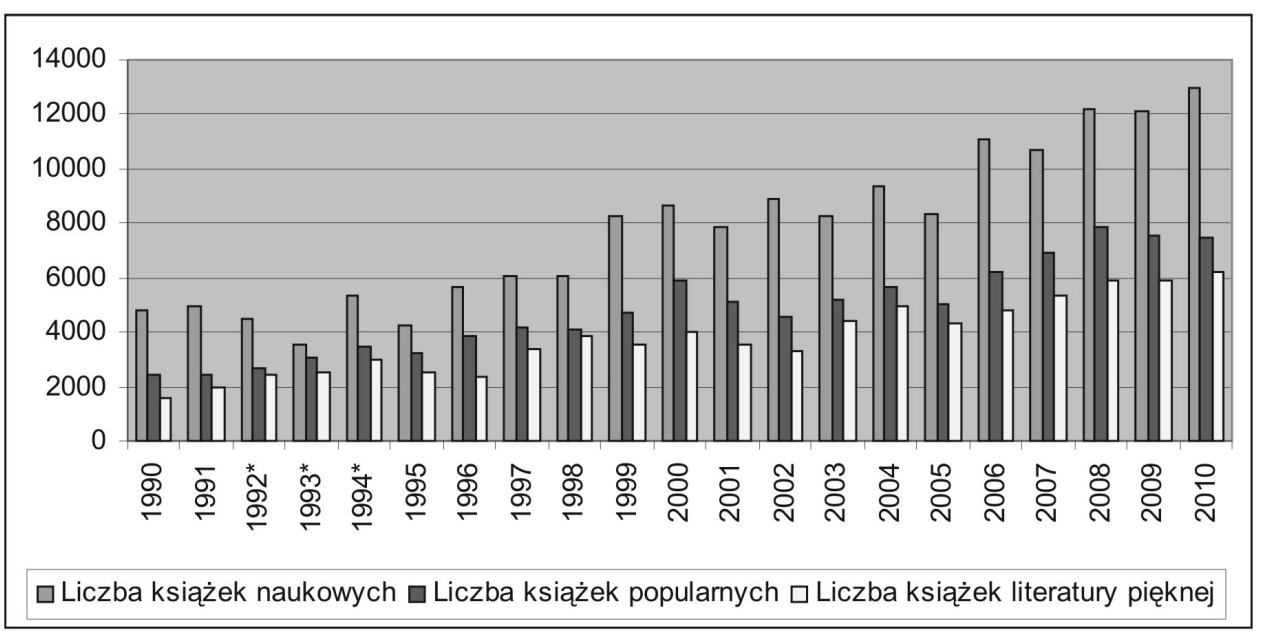

Wykres 2. Książki według typów

Jak widać, najbardziej intensywnie rozwijała się książka naukowa, w drugiej kolejności książka popularna. Nieco niższy wskaźnik rozwoju ma książka literacka. W porównaniu z rokiem 1990 wszystkie typy książek wykazują tendencję wzrostową.

\section{Książka literacka}

Analiza proporcji liczby książek literackich polskich i obcych w latach 19902010 wskazuje wyraźne zmniejszanie się liczby tytułów autorów polskich w stosunku do autorów obcych (tab. 3). O ile przed rokiem 1990 wskaźnik ten kształ- 
tował się w proporcjach ok. $75 \%$ (literatura polska) do 25\% (literatura obca), to po roku 1990 proporcje te zaczynają się zdecydowanie zmieniać na korzyść literatury obcej. W roku 2010 literatura obca osiagnęła $58,5 \%$.

Tabela 3

Liczba książek literatury pięknej autorów polskich i obcych

\begin{tabular}{|c|c|c|c|c|}
\hline Rok & Autorzy polscy & Autorzy obcy & $\begin{array}{c}\text { Wskaźnik \% } \\
\text { literatury polskiej }\end{array}$ & $\begin{array}{c}\text { Wskaźnik \% } \\
\text { literatury obcej }\end{array}$ \\
\hline 1990 & 1061 & 512 & 67,5 & 32,5 \\
\hline 1991 & 1148 & 848 & 57,5 & 42,5 \\
\hline $1992^{*}$ & 1164 & 1215 & 48,9 & 51,1 \\
\hline $1993^{*}$ & 959 & 1411 & 40,5 & 59,5 \\
\hline $1994^{*}$ & 1143 & 1528 & 42,8 & 57,2 \\
\hline 1995 & 1199 & 1357 & 46,9 & 53,1 \\
\hline 1996 & 1271 & 1126 & 52,0 & 48,0 \\
\hline 1997 & 1783 & 1582 & 53,0 & 47,0 \\
\hline 1998 & 1872 & 1967 & 48,8 & 51,2 \\
\hline 1999 & 1898 & 1662 & 46,7 & 53,3 \\
\hline 2000 & 2122 & 1896 & 52,8 & 47,2 \\
\hline 2001 & 2016 & 1507 & 57,2 & 42,8 \\
\hline 2002 & 1805 & 1498 & 54,6 & 45,4 \\
\hline 2003 & 2336 & 2093 & 52,7 & 47,3 \\
\hline 2004 & 2528 & 2445 & 50,8 & 49,2 \\
\hline 2005 & 2215 & 2093 & 51,4 & 48,6 \\
\hline 2006 & 2721 & 2061 & 56,9 & 43,1 \\
\hline 2007 & 2837 & 2497 & 53,2 & 46,8 \\
\hline 2008 & 2915 & 3020 & 49,1 & 50,9 \\
\hline 2009 & 2972 & 2912 & 50,5 & 49,5 \\
\hline 2010 & 2571 & 2137 & 41,5 & 58,5 \\
\hline
\end{tabular}

Źródło: Opracowanie własne na podstawie „Ruchu Wydawniczego w Liczbach”.

*Dane z lat 1992-1994 nieskorygowane, przejęte z poszczególnych roczników.

W wielu latach wskaźnik literatury obcej oscylował w granicach $50 \%$. Praktycznie można więc uznać, że stosunek liczby książek literatury polskiej i obcej kształtował się po roku 1990 jak 1:1. Zainteresowanie literaturą piękną zagraniczna jest, jak się wydaje, wynikiem „odreagowania” czytelników na ograniczenia okresu polityki wydawniczej realizowanej centralnie przez czynniki państwowe w okresie PRL. Jest to także bezpośredni efekt łatwości w indywidualnym zakupie praw autorskich do dzieł zagranicznych. 


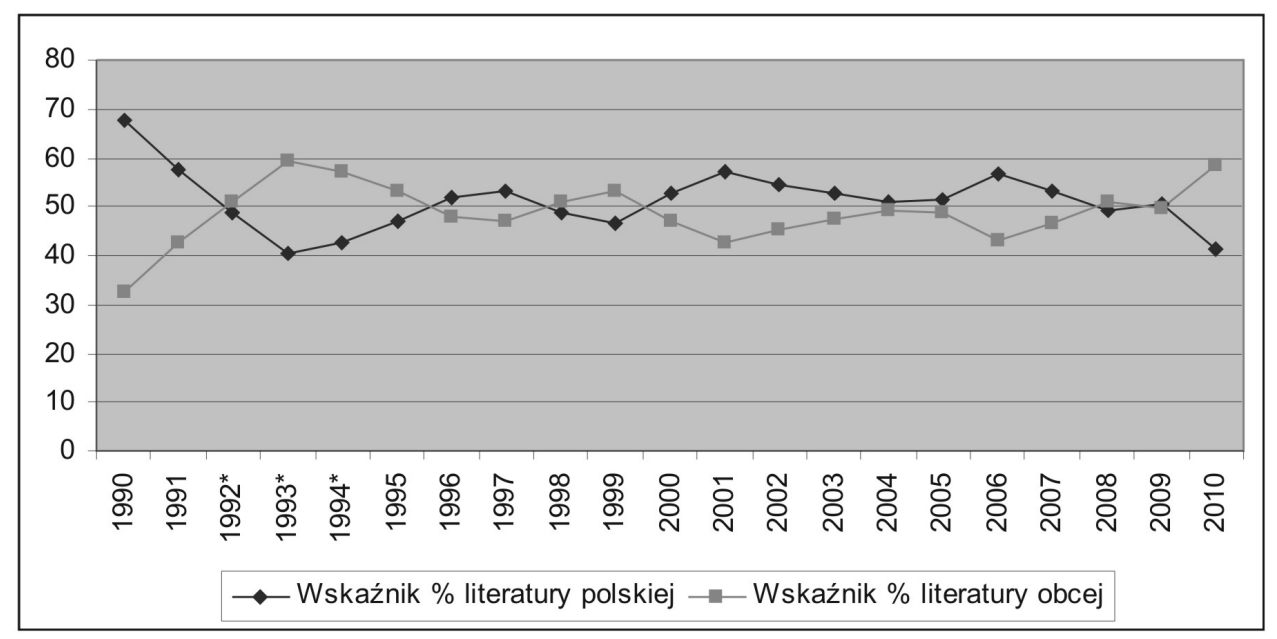

Wykres 3. Wskaźniki procentowe literatury pięknej autorów polskich i obcych

Interesujące jest spojrzenie na języki oryginałów, zwłaszcza jeśli porównamy je z okresem wcześniejszym. Przede wszystkim można powiedzieć, że liczba przekładów w poszczególnych dekadach do lat dziewięćdziesiątych była dosyć stabilna, natomiast w ostatniej dekadzie przekłady stanowią $56 \%$ przekładów z całego okresu 1944-2010. Inaczej mówiąc, w ostatniej dekadzie wydano więcej przekładów niż w ciągu poprzednich 50 lat. Jeśli chodzi o języki oryginału, to w porównaniu z pierwszą dekadą powojenną (1944-1955) widoczny jest siedmiokrotny wzrost liczby tłumaczeń z języka angielskiego, co jest niewątpliwie skutkiem ekspansji globalnej tego języka, a także aktywności literackiej pisarzy amerykańskich, brytyjskich, australijskich, kanadyjskich. Drugie spostrzeżenie, to ponad trzykrotny spadek przekładów z języka rosyjskiego ${ }^{7}$, o czym zapewne zdecydowały obiekcje wydawców wynikające z przeszłości, gdy literatura rosyjska (i narodów ZSRR) ze względów ideologicznych i politycznych była tłumaczona i wydawana częściej niż literatura krajów zachodnich. Kolejna uwaga, to prawie sześciokrotny wzrost liczby przekładów z języka niemieckiego (wcześniej ograniczenia w przekładach literatury RFN) i ponad czterokrotny z francuskiego, choć w liczebności przekładów przewagę ma literatura francuskojęzyczna. Szczegóły ilustruje tabela 4.

7 Trzeba jednak uwzględnić fakt, że do czasu rozpadu ZSRR statystyka wydawnicza włączała tu także ksiażki w innych językach republik radzieckich, dlatego wskaźniki te w rzeczywistości mogą być nieco korzystniejsze. 
Przekłady literatury pięknej obcej na język polski w latach 1944-2010

Tabela 4

według najbardziej popularnych języków

\begin{tabular}{|c|c|c|c|c|c|}
\hline Lata & $\begin{array}{c}\text { Przekłady lite- } \\
\text { rackie ogółem }\end{array}$ & $\begin{array}{c}\text { Z języka } \\
\text { angielskiego }\end{array}$ & $\begin{array}{c}\text { Z języka } \\
\text { francuskiego }\end{array}$ & $\begin{array}{c}\text { Z języka } \\
\text { niemieckiego }\end{array}$ & $\begin{array}{c}\text { Z języka } \\
\text { rosyjskiego }\end{array}$ \\
\hline $1944-2010$ & 54817 & 29721 & 5015 & 4141 & 5852 \\
\hline $1944-1955$ & 4340 & 680 & 504 & 307 & 2257 \\
\hline $1956-1965$ & 3761 & 970 & 596 & 434 & 931 \\
\hline $1966-1975$ & 3580 & 989 & 418 & 371 & 762 \\
\hline $1976-1985$ & 3592 & 854 & 396 & 367 & 732 \\
\hline $1986-1995$ & 8577 & 5095 & 790 & 824 & 551 \\
\hline $1996-2010$ & 30967 & 21133 & 2309 & 1838 & 619 \\
\hline
\end{tabular}

Źródło: „Ruch Wydawniczy w Liczbach” 2010, R. 56, tab. 43.

Ze względu na kraje pochodzenia literatury pięknej, największy udział ma literatura amerykańska i brytyjska, na trzecim miejscu jest literatura francuska, na czwartym niemiecka. Zwraca uwage zainteresowanie literatura norweska, która rozpoczynała w 1990 r. liczbą 5 tytułów, by w latach 2009-2010 dojść do 290 tytułów. Zwiększyło się też wyraźnie zainteresowanie wydawców (a więc i czytelników) literaturą hiszpańską (choć już w latach sześćdziesiątych i siedemdziesiątych wydawano sporo literatury iberoamerykańskiej), szwedzka, włoska, kanadyjska, australijską. Dla porównania liczba książek literatury pięknej z wybranych krajów w kilku wybranych latach (tab. 5).

Tabela 5

Literatura piękna obca według wybranych krajów pochodzenia autora w latach 1990-1991, 1995-1996, 2000-2001, 2005-2006, 2009-2010

\begin{tabular}{|l|r|r|r|r|r|}
\hline \multirow{2}{*}{ Kraj } & \multicolumn{5}{c|}{ Liczba książek w latach } \\
\cline { 2 - 6 } & $1990-1991$ & $1995-1996$ & $\mathbf{2 0 0 0 - 2 0 0 1}$ & $\mathbf{2 0 0 5 - 2 0 0 6}$ & $\mathbf{2 0 0 9 - 2 0 1 0}$ \\
\hline Australia & $\mathbf{4}$ & $\mathbf{1 5}$ & 15 & $\mathbf{6 9}$ & $\mathbf{8 9}$ \\
\hline Austria & 10 & 21 & 30 & 35 & 30 \\
\hline Belgia & 31 & 26 & 35 & 100 & 55 \\
\hline Czechosłowacja & 34 & 14 & 39 & 31 & 54 \\
\hline Dania & 13 & 13 & 19 & 28 & 24 \\
\hline Finlandia & 9 & 11 & - & 20 & 16 \\
\hline Francja & 161 & 130 & 199 & 241 & 361 \\
\hline Hiszpania & 7 & 17 & 44 & 66 & 132 \\
\hline Kanada & 39 & 121 & 119 & 79 & 112 \\
\hline Niemcy & 127 & 185 & 170 & 207 & 299 \\
\hline Norwegia & 5 & 43 & 62 & 47 & 290 \\
\hline Stany Zjednoczone & 362 & 951 & 1390 & 1520 & 1900 \\
\hline Szwecja & 23 & 25 & 51 & 48 & 151 \\
\hline Wielka Brytania & 329 & 590 & 705 & 915 & 1413 \\
\hline Włochy & 28 & 46 & 109 & 124 & 171 \\
\hline ZSRR/Rosja & 88 & 51 & 72 & 122 & 118 \\
\hline
\end{tabular}

Źródło: Opracowanie własne na podstawie „Ruchu Wydawniczego w Liczbach”. 
Porównując udział literatury dla dzieci i młodzieży oraz literatury dla dorosłych można stwierdzić, że w latach dziewięćdziesiątych wskaźnik kształtował się w proporcjach ok. $80 \%$ (literatura dla dorosłych) do ok. $20 \%$ (dla dzieci i młodzieży, z wyjatkiem 1997 r.). Po krótkotrwałym spadku w końcu lat dziewięćdziesiątych wskaźnik literatury dla dorosłych wzrósł ponownie w okresie 2001-2003, ale już od roku 2004 zauważalna jest wyraźna tendencja wzrostowa literatury dla dzieci i młodzieży, sięgająca prawie 29\% w 2009 r. Szczegóły ilustruje tabela 6 oraz wykres 4 .

Tabela 6

Literatura piękna dla dorosłych oraz dla dzieci i młodzieży

\begin{tabular}{|c|c|c|c|c|}
\hline Rok & $\begin{array}{l}\text { Liczba książek } \\
\text { literatury pięknej } \\
\text { dla dorosłych }\end{array}$ & $\begin{array}{l}\text { Literatura piękna } \\
\text { dla dzieci } \\
\text { i młodzieży }\end{array}$ & $\begin{array}{l}\text { Wskaźnik \% } \\
\text { literatury } \\
\text { dla dorosłych }\end{array}$ & $\begin{array}{l}\text { Wskaźnik \% } \\
\text { literatury dla dzieci } \\
\text { i młodzieży }\end{array}$ \\
\hline 1990 & 1237 & 336 & 78,6 & 21,4 \\
\hline 1991 & 1555 & 441 & 77,9 & 22,1 \\
\hline 1992 & 1966 & 434 & 82,1 & 17,9 \\
\hline 1993 & 2002 & 482 & 80,6 & 19,4 \\
\hline 1994 & 2441 & 560 & 77,0 & 22,9 \\
\hline 1995 & 2065 & 491 & 80,8 & 19,2 \\
\hline 1996 & 1925 & 472 & 80,3 & 19,7 \\
\hline 1997 & 2538 & 827 & 75,4 & 24,6 \\
\hline 1998 & 3043 & 796 & 79,3 & 20,7 \\
\hline 1999 & 2755 & 805 & 77,4 & 22,6 \\
\hline 2000 & 3208 & 810 & 77,0 & 23,0 \\
\hline 2001 & 2868 & 655 & 81,4 & 18,6 \\
\hline 2002 & 2802 & 501 & 84,8 & 15,2 \\
\hline 2003 & 3590 & 839 & 81,0 & 18,9 \\
\hline 2004 & 3654 & 1319 & 73,5 & 26,5 \\
\hline 2005 & 3252 & 1056 & 75,5 & 24,5 \\
\hline 2006 & 3679 & 1103 & 76,9 & 23,1 \\
\hline 2007 & 3909 & 1425 & 73,3 & 26,7 \\
\hline 2008 & 4316 & 1619 & 72,7 & 27,3 \\
\hline 2009 & 4185 & 1699 & 71,1 & 28,9 \\
\hline 2010 & 4708 & 1482 & 76,0 & 23,9 \\
\hline
\end{tabular}

Źródło: Opracowanie własne na podstawie „Ruchu Wydawniczego w Liczbach”. 


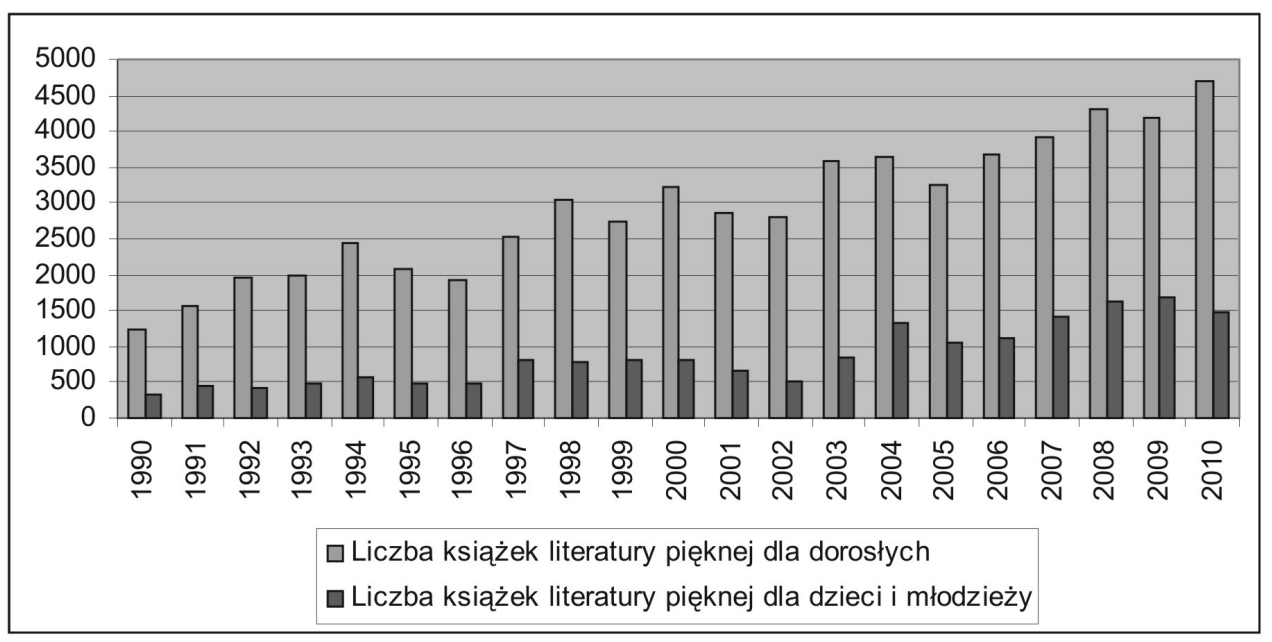

Wykres 4. Literatura piękna dla dorosłych i literatura piękna dla dzieci i młodzieży

\title{
Pisarze polscy i edycje ich dzieł
}

Warto też spojrzeć na liczbę wydań dzieł poszczególnych pisarzy polskich i zagranicznych oraz na konkretne dzieła w perspektywie całego okresu powojennego 1944-2010, po transformacji społeczno-ustrojowej, tj. w okresie 1991-20108 oraz w roku 2010. Jest to w jakimś stopniu odzwierciedlenie zainteresowania czytelniczego twórczością literacką konkretnych pisarzy i konkretnymi dziełami.

\section{Lista rangowa polskich pisarzy według liczby wydań (ponad 300) ich dzieł w latach 1944-2010}

\author{
Henryk Sienkiewicz - 946 wydań \\ Józef Ignacy Kraszewski - 642 \\ Adam Mickiewicz - 602 \\ Bolesław Prus - 590 \\ Stefan Żeromski - 543 \\ Maria Konopnicka - 530 \\ Jan Brzechwa - 495 \\ Juliusz Słowacki - 390 \\ Julian Tuwim - 368 \\ Ewa Szelburg-Zarembina -312 \\ Eliza Orzeszkowa - 310 \\ Mieczysław Maliński - 309
}

${ }^{8}$ Przyjęcie jako początkowego roku 1991 jest uwarunkowane brakiem indywidualnych danych dla części autorów, a zwłaszcza tytułów dzieł w „Ruchu Wydawniczym w Liczbach”. Dane za rok 1990 podane są łącznie za okres 1986-1990. 
Pisarze, z wyjątkiem ostatniego, M. Malińskiego (autor książek o papieżu Janie Pawle II), należą do polskiej klasyki, a ich książki w większości były lekturami szkolnymi, co miało istotny wpływ na liczbę wydań.

\title{
Lista rangowa polskich pisarzy według liczby wydań (ponad 100) ich dzieł w latach 1991-2010
}

\author{
Henryk Sienkiewicz - 394 wydania \\ Jan Twardowski - 270 \\ Adam Mickiewicz - 236 \\ Maria Konopnicka - 234 \\ Joanna Chmielewska - 216 \\ Julian Tuwim - 186 \\ Mieczysław Maliński - 176 \\ Ewa Stadtmüller - 173 \\ Stefan Żeromski - 170 \\ Jan Brzechwa - 165 \\ Bolesław Prus - 165 \\ Ryszard Kapuściński - 151 \\ Stanisław Lem - 137 \\ Kornel Makuszyński - 125 \\ Bogumiła Konstancja Załęska - 114 \\ Aleksander Fredro - 106 \\ Juliusz Słowacki - 105
}

Na liście pisarzy, którzy w latach 1991-2010 mieli ponad 100 wydań swoich dzieł znaleźli się autorzy cieszący się powodzeniem czytelników w całym okresie powojennym (Sienkiewicz, Mickiewicz, Żeromski, Prus, Słowacki, Fredro), znani autorzy książek dla dzieci i młodzieży (Konopnicka, Tuwim, Brzechwa, Makuszyński). Ale nie znalazł się na niej już J. I. Kraszewski, a także E. Orzeszkowa. Pojawiły się natomiast zupełnie nowe nazwiska bardzo wysoko notowane, jak: ksiądz Jan Twardowski - poeta, Joanna Chmielewska - autorka powieści typu kryminalnego, Ewa Stadtmüller - autorka książek dla dzieci, Ryszard Kapuściński - autor popularnych reportaży zagranicznych, Stanisław Lem - najwybitniejszy polski przedstawiciel powieści science fiction, Bogumiła Konstancja Załęska - poetka.

\section{Lista rangowa polskich pisarzy według liczby wydań (ponad 5) w 2010 r.}

Marian Piotr Rawinis - 36 wydań

Andrzej Juliusz Sarwa -18

Joanna Chmielewska - 18

Tadeusz Konwicki - 13

Stanisław Lem - 8

Andrzej Pilipiuk - 8 
Ewa Skarżyńska - 8

Jan Twardowski - 7

Maria Nurowska - 6

Beata Ostrowicka - 6

Jacek Piekara - 6

Jak widać, dwa pierwsze miejsca z wysoką liczbą wydań zajmują nowi pisarze: Rawinis i Sarwa. Dorównuje im Chmielewska.

\section{Lista rangowa najczęściej wydawanych (ponad 30 wydań) dzieł polskich pisarzy w latach 1991-2010}

Henryk Sienkiewicz W pustyni i w puszczy - 74 wydania

Adam Mickiewicz Pan Tadeusz - 73

Henryk Jerzy Chmielewski Tytus, Romek i A'Tomek - 57

Henryk Sienkiewicz Quo vadis - 51

Aleksander Fredro Zemsta - 45

Henryk Sienkiewicz Krzyżacy - 45

Maria Konopnicka O krasnoludkach i sierotce Marysi - 41

Adam Mickiewicz Dziady - 40

Henryk Sienkiewicz Ogniem i mieczem - 38

Stefan Żeromski Syzyfowe prace - 37

Henryk Sienkiewicz Janko Muzykant - 35

Stanisław Wyspiański Wesele - 35

Henryk Sienkiewicz Latarnik - 34

Henryk Sienkiewicz Potop - 33

Henryk Sienkiewicz Pan Wołodyjowski - 32

Bolesław Prus Lalka - 31

Dzieła najczęściej wydawane w latach 1991-2010 w większości są lekturami szkolnymi (Pan Tadeusz, Zemsta, Dziady, Syzyfowe prace, Janko Muzykant, Latarnik, Wesele, Lalka, Odprawa posłów greckich). Interesujący wyjątek stanowi komiks Henryka Chmielewskiego Tytus, Romek i A'Tomek oraz książka Marii Konopnickiej O krasnoludkach i sierotce Marysi. Jak widać, zainteresowaniem cieszą się książki Henryka Sienkiewicza, które tylko w części są lub były lekturami szkolnymi.

Trzeba też zwrócić uwagę na niektóre nazwiska polskich pisarzy, których dzieła po roku 1990 nie były wydawane lub wydawano pojedyncze tytuły. Można przypuszczać, że czytelnicy nie sa już zainteresowani ich twórczościa, ale też trzeba pamiętać, że ich dzieła wydawane dawniej w wysokich nakładach są dostępne w bibliotekach. Do grupy niewydawanych należą dosyć znani pisarze, jak np.: Halina Auderska, Helena Bobińska, Helena Boguszewska, Tadeusz Breza, Janina Broniewska, Stanisław Ryszard Dobrowolski, Wanda Grodzieńska, Tadeusz Hołuj, Ireneusz Iredyński, Anna Kowalska, Kazimierz Koźniewski, Sławomir Kryska, Jan Edward Kucharski, Jalu Kurek, Hanna Mortkowicz-Olczakowa, Jan Edmund Osmańczyk, Leon Pasternak, Michał Rusinek, Irena Tuwim, Wanda Wasilewska, Jan Wiktor, Hanna Zdzitowiecka. 


\title{
Pisarze obcy i edycje ich dzieł
}

Podobna analiza przeprowadzona dla twórczości pisarzy zagranicznych wskazuje, że tu także w ostatnich 20 latach są autorzy cieszący się niezmiennym zainteresowaniem czytelników, ale pojawiły się także nowe, wysoko notowane nazwiska.

\section{Lista rangowa pisarzy obcych według liczby wydań (ponad 150) ich dzieł w latach 1944-2010}

\author{
Lucy Maud Montgomery - 327 wydań \\ William Shakespeare -312 \\ Agatha Christie - 309 \\ Hans Christian Andersen - 279 \\ Astrid Lindgren - 267 \\ Walt Disney - 257 \\ Danielle Steel - 246 \\ Jules Verne - 244 \\ Margit Sandemo - 241 \\ Nora Roberts - 211 \\ Hedwig Courts-Mahler - 188 \\ Jack London - 187 \\ Mark Twain - 186 \\ Graham Masterton - 171 \\ Honore de Balzac - 164 \\ Joseph Conrad - 164 \\ Stephen King - 156 \\ Karl May - 153 \\ Gool Van - 153
}

Wśród autorów o najwyższej i wysokiej liczbie wydań dzieł są klasycy literatury dziecięcej (W. Disney), młodzieżowej (L. M. Montgomery, A. Lindgren, J. Verne, M. Twain, K. May), autorka klasycznych kryminałów A. Christie, niemiecka autorka powieści psychologiczno-romansowych $\mathrm{H}$. Courts-Mahler, autorzy książek przygodowych (J. London, J. Conrad, K. May). Wśród nowych autorów warto odnotować wysoką pozycję amerykańskich autorek romansów Danielle Steel i Nory Roberts oraz norweskiej pisarki Margit Sandemo - autorki serii Saga o Ludziach Lodu.

\section{Lista rangowa pisarzy obcych według liczby wydań (ponad 100) ich dzieł w latach 1991-2010}

Agatha Christie - 279 wydań

Lucy Maud Montgomery - 253

Walt Disney -243 


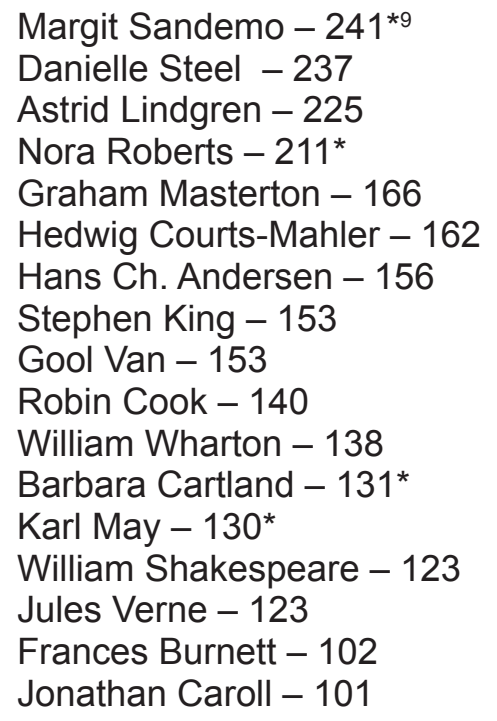

Na liście tej znajduje się połowa pisarzy, którzy karierę literacką rozpoczynali w przeszłości (Christie, Montgomery, Disney, Lindgren, Courts-Mahler, Andersen, Verne, May, Burnett, Shakespeare) i pisarze współcześni, których twórczość w większości przypada na ostatnie trzydziestolecie, przy czym część z nich zajmuje bardzo wysokie pozycje na liście rangowej, jak wspomniane już amerykańskie autorki powieści dla kobiet (Danielle Steel i Nora Roberts) oraz Norweżka Margit Sandemo, brytyjski autor horrorów Graham Masterton, amerykański pisarz powieści grozy Stephen King, autor thrillerów Robin Cook czy autor książek dla dzieci Gool Van.

Lista rangowa pisarzy obcych według liczby wydań (ponad 5) w 2010 r.

Frid Ingulstad - 54 wydania

Trine Angelsen - 30

Ann-Christin Gjersøe - 23

Robert Muchamore - 13

Danielle Steel - 13

Anne Rice - 12

Terry Goodkind - 11

Agatha Christie - 9

Robin Cook - 9

Henning Mankell - 9

Gabriel Garcia Marquez - 8

Nora Roberts - 8

Diana Gabaldon - 7

Stephen King - 7

Jules Verne - 6

${ }^{9} \mathrm{~W}$ przypadkach oznaczonych gwiazdką może być niewielki błąd wynikający z grupowego podania liczby wydań za okres 1986-1995. 
Jak widać z przedstawionej listy, z wyjątkiem A. Christie, J. Verne'a, G. G. Marqueza, mamy tu już zdecydowaną przewagę nowych autorów, przy czym zwraca uwagę zainteresowanie polskich czytelników literaturą norweską - trzy pierwsze miejsca zajmuja pisarki norweskie.

\section{Lista rangowa najczęściej wydawanych (ponad 40 wydań) dzieł pisarzy obcych w latach 1944-2010}

Hans Ch. Andersen: Baśnie - 123 wydania

Daniel Defoe: Robinson Crusoe - 97

Jacob i Wilhelm Grimm: Baśnie - 70

Carlo Collodi: Pinokio - 64

Mark Twain: Przygody Tomka Sawyera - 61

Sofokles: Antygona - 60

Frances Burnett: Tajemniczy ogród - 58

William Shakespeare: Makbet - 57

William Shakespeare: Hamlet - 55

Lucy M. Montgomery: Ania z Zielonego Wzgórza - 51

Antoine de Saint-Exupery: Mały Książę - 50

Mark Twain: Królewicz i żebrak - 48

Alan A. Milne: Kubuś Puchatek - 47

William Shakespeare: Romeo i Julia - 47

Jules Verne: $W 80$ dni dookoła świata - 46

Hans Ch. Andersen: Calineczka - Brzydkie kaczątko - Dziecię elfów - 44

Molier: Świętoszek - 44

Charles Dickens: Opowieść wigilijna - 43

Ferenc Molnar: Chłopcy z Placu Broni - 41

Robert L. Stevenson: Wyspa skarbów - 41

Warto zauważyć, że wśród najczęściej wydawanych tytułów są nazwiska znanych pisarzy książek dla dzieci i młodzieży: Andersen, bracia Grimm, Montgomery, Verne, Twain, Collodi, Burnett, Milne, Molnar, Defoe. Książki tych autorów cieszyły się powodzeniem także przed rokiem 1990. Trzeba jednak zwrócić uwagę, że część z nich to lektury szkolne, co sprawia, że były częściej wydawane (książki Shakespeare’a, Sofoklesa, Moliera). Niemniej jednak w grupie tej znajduja się książki, które interesują kolejne pokolenia, zwłaszcza młodych czytelników, a potwierdzaja to wydania z ostatnich 20 lat. Do takich dzieł należą z pewnością: Pinokio, Ania z Zielonego Wzgórza, Przygody Tomka Sawyera, Mały Książę, Kubuś Puchatek, Dzieci z Bullerbyn czy W 80 dni dookoła świata. Warto też podkreślić wysokie miejsce w latach 1991-2010 Mistrza i Małgorzaty M. Bułhakowa. 


\title{
Lista rangowa najczęściej wydawanych (ponad 20 wydań) dzieł pisarzy obcych w latach 1991-2010
}

\author{
Hans Ch. Andersen Baśnie - 75 wydań \\ Daniel Defoe Robinson Crusoe - 58 \\ Jacob i Wilhelm Grimm Baśnie - 53 \\ Frances Burnett Tajemniczy ogród - 46 \\ Carlo Collodi Pinokio - 45 \\ Lucy Maud Montgomery Ania z Zielonego Wzgórza - 40 \\ Mark Twain Przygody Tomka Sawyera - 36 \\ Antoine Saint-Exupery Mały książę - 35 \\ Charles Dickens Opowieść wigilijna - 34 \\ Sofokles Antygona - 31 \\ William Shakespeare Romeo i Julia - 30 \\ Hans Ch. Andersen Calineczka - dziecię elfów - 28 \\ Joseph Bedier Dzieje Tristana i Izoldy - 28 \\ Michaił Bułhakow Mistrz i Małgorzata - 28 \\ Alan Alexander Milne Kubuś Puchatek - 28 \\ William Shakespeare Makbet - 28 \\ Frances Burnett Mała księżniczka - 26 \\ Jules Verne $W 80$ dni dookoła świata - 25 \\ Astrid Lindgren Dzieci z Bullerbyn - 24 \\ Charles Perrault Bajki - 24 \\ Robert Louis Stevenson Wyspa skarbów - 24 \\ William Shakespeare Hamlet - 24 \\ Lewis Carroll Alicja w krainie czarów - 23 \\ Alan Alexander Milne Chatka Puchatka - 23
}

Rynek wydawniczy po roku 1990 zmienił się i niektórzy popularni do tej pory wśród wydawców pisarze zagraniczni przestali być poszukiwani przez czytelników. Należą do nich: Louis Aragon, Korniej Czukowski, Jan Drda, Aleksander Fadiejew, Juliusz Fučik, Arkady Gajdar, Maksym Gorki, Daniel Granin, Aleksander Grin, Walentyn Katajew, Michał Lermontow, Maurice Maeterlinck, Heinrich Mann, Bruce Marshall, Francais Mauriac, Martin Andersen Nexö, Konstanty Paustowski, Borys Polewoj, Anna Seghers, George Bernard Shaw, Konstanty Simonow, Władimir Tendriakow, Aleksiej Tołstoj, Iwan Turgeniew, Ethel Lilian Voynich, Anatolij Winogradow. Jak widać, w grupie tej znalazło się najwięcej pisarzy rosyjskich, których twórczość, zwłaszcza w latach czterdziestych i pięćdziesiątych, była często wydawana. Dziś z tej listy na rynku książki pojawiaja się pojedyncze tytuły wymienionych autorów.

\section{Wnioski}

Analiza statystyczna literatury pięknej w Polsce po 1990 r. pozwala stwierdzić, że liczba książek literackich w ciągu 20 lat wzrosła czterokrotnie, z 1573 w 1990 r. do 6190 w 2010, ale jednocześnie udział literatury pięknej w ogólnej 
liczbie książek wydawanych w tym czasie wzrósł tylko o kilka punktów, kształtując się na poziomie od ok. 16 do ok. 23 punktów (w 1990 - 15,3, w 2010 - 20,9). Zmieniły się natomiast wyraźnie proporcje książek autorów polskich i obcych. O ile przed rokiem 1990 była to relacja $75 \%$ polskich do $25 \%$ obcych, o tyle w latach późniejszych proporcje te wyrównały się. W przekładach zdecydowaną przewagę ma literatura pochodzenia amerykańskiego i brytyjskiego.

W odniesieniu do polskich autorów pierwsze miejsce w całym okresie powojennym i ostatnim dwudziestoleciu zajmuje twórczość Henryka Sienkiewicza, który zdecydowanie dystansuje innych autorów, osiagając w okresie 1944-2010 prawie 950 wydań swoich dzieł. Wysokie miejsca zajmują współcześni autorzy reprezentujący różne gatunki literackie jak: ks. Jan Twardowski (poezja), Joanna Chmielewska (powieść), Henryk Chmielewski (komiks). W przypadku autorów zagranicznych najwyższe miejsca zajmuja klasycy książek dla dzieci i młodzieży: Lucy M. Montgomery, Astrid Lindgren, Frances Burnett, Hans Ch. Andersen, również Agatha Christie jako najpopularniejsza autorka powieści kryminalnej, ale pojawiają się nowi autorzy, głównie z kręgu literatury amerykańskiej, brytyjskiej, skandynawskiej. Wysokie miejsca zajmują też polscy i obcy autorzy lektur szkolnych.

\section{Bibliografia}

„Ruch Wydawniczy w Liczbach”. Roczniki z lat 1990-2010. Biblioteka Narodowa.

Uwagi wstępne. „Ruch Wydawniczy w Liczbach” 2004, R. 50, Warszawa 2005, s. 5-12.

\section{Opracowania}

Korczyńska-Derkacz M.: Książka naukowa w Polsce w latach 1991-2005 - tendencje rozwojowe. „Zagadnienia Informacji Naukowej” 2006, nr 2, s. 91-108.

Musioł A.: Książka zagraniczna w Polsce w latach 1991-2010 w świetle statystyki. „Zagadnienia Informacji Naukowej" 2011, nr 2, s. 89-101.

Sadowska J.: Wybrane aspekty polskiego rynku wydawniczego po 1989 r. w świetle statystyki. „Zagadnienia Informacji Naukowej” 2004, nr 2, s. 30-40.

\section{Summary}

The article describes development trends of literature in Poland after social and political transformation. The author presents numbers of literary titles published in Poland in 1990-2010, number of such titles for adult readers and for children and youth, and number of translations. She compiles ranking lists of Polish and foreign authors by editions in 1944-2010 and 1990-2010, as well as ranking lists of Polish and foreign literary titles most often published in Poland in these periods. These data were taken from the statistics "Polish Publishing in Figures" annually for the years 1990-2010, published by the National Library on the base of current national bibliography. 